\title{
OBITUARIES/HULDEBLYKE
}

sy ma se bed gesit het en musiek gespeel het totdat hy in die wêreld gekom het. Was dit dalk die voorspel tot sy latere liefde vir musiek? Sy moeder het gesterf toe hy maar 3 maande oud was.

In 1952 matrikuleer Frans aan die Jan Malan Hoërskool op Koringberg, waarna hy laboratorium-tegnikus was by die De Hoek sementfabriek. In 1965 behaal hy die graad $\mathrm{MB} \mathrm{ChB}$ aan die Universiteit van Stellenbosch. In 1965 doen hy sy internskap by Karl Bremer Hospitaal in Bellville, waarna hy tot 1974 as algemene praktisyn in Keetmanshoop en Clanwilliam gewerk het.

Frans was van jongs af lief vir vlieg en het gereeld sy ernstig siek pasiënte self na Kaapstad vervoer. Hierdie liefde het hy ook aan sy dogters oorgedra.

Op 15 Januarie 1974 begin hy as kliniese assistent in die Departement Dermatologie by Tygerberg Hospitaal waar hy in Desember 1978 die graad MMed (Derm) aan die Universiteit van Stellenbosch behaal. Tydens sy jare as kliniese assistent in die Departement Dermatologie het ek vir Frans baie goed leer ken en het ons jarelange vriendskap begin. Menige aande na 'n lang joernaalbespreking by Frans se huis, het hy ons met pragtige orrelspel vermaak; ook met saksofoon en klavier was hy vaardig.

Sy dermatologie-loopbaan het in Windhoek begin en geëindig, waar hy staatssowel as privaatpasiënte behandel het. 'n Meer pligsgetroue en toegewyde geneesheer kon 'n mens nie in daardie geweste kry nie. Hy is gerespekteer deur sy kollegas en pasiënte in Windhoek en was gereeld in kontak met sy kollegas en vriende in Suid-Afrika. Hy het gereeld die jaarlikse dermatologie-kongresse in Suid-Afrika bygewoon en sodoende ook akademies met die ontwikkelinge op sy vakgebied bygebly. Frans het 'n baie groot liefde vir die Namibiese natuurskoon gehad, en menige van ons sal lewenslank angename herinneringe hê aan safari's saam met hom deur die Kaokoveld tot by die Kunenerivier.

Frans is op 16 November 1967 met Esna Baard op Malmesbury getroud en 2 dogters, Maryke en Hanlie, is uit die huwelik gebore. Ons simpatie gaan uit na Esna, Maryke, Hanlie en Geoff (skoonseun) en die kleinkinders, Andrea en Robin.

Dankie aan die Vader vir 'n geliefde vriend en pligsgetroue geneesheer wat ons baie sal mis.

\section{Edgar Swart}

Bellville 